\title{
Role of lipids in the extrusion cooking processes
}

\author{
By S. Ilo, Regine Schoenlechner and E. Berghofe
}

Institute of Food Technology, University of Agricultural Sciences, Vienna Muthgasse, 18, A-1190 Vienna, Austria

\begin{abstract}
RESUMEN
Papel de los lípidos en los procesos de cocción-extrusión

La extrusión es, en general, una tecnología versátil y muy eficiente, que se aplica ampliamente en la elaboración de alimentos y piensos. Los equipos de cocción-extrusión tienen numerosas aplicaciones, entre las que pueden incluirse: los cereales de desayuno listos para comer, los aperitivos, diferentes productos basados en cereales, los piensos para animales domésticos y peces, proteínas vegetales texturizadas, productos de pastelería, reacciones químicas y bioquímicas, y la extracción de aceites. Los lípidos son componentes que juegan un papel importante en la mayoría de los procesos de cocción-extrusión. Pueden actuar como plastificantes o como emulsionantes, suministrando lubricación. En este artículo se revisan con detalle los efectos de las reacciones de los aceites y otros lípidos durante el proceso de cocción-extrucción así como el efecto de la formación de complejos amilasa-lípidos sobre la calidad de los extrudados.
\end{abstract}

PALABRAS-CLAVE: Alimentos - Calidad - Cocciónextrusión - Lípidos - Piensos.

\section{SUMMARY}

\section{Role of lipids in the extrusion cooking processes}

Extrusion is a versatile and very efficient technology that is widely used in food and feed processing. The cooking extruders have found many applications, which include: breakfast cereals, snack foods, other cereal based products, pet food and aquatic foods, texturized vegetable proteins, confectionery products, chemical and biochemical reactions, and oil extraction. Lipids are components that play an important role in most of the extrusion cooking processes. They can act as plastificizers or emulsifiers, and affect more significantly texture and stickiness of the extrudate. This paper reviews effect of oils and other lipids reactions during extrusion cooking as well as the effects of amylase-lipid complexation on extrudate quality.

KEY-WORDS: Extrusion-cooking - Feed -Foods - Lipids - Quality.

\section{INTRODUCTION}

Extrusion in general is a versatile and very efficient technology that is widely used in food and feed processing. The process of extrusion of foods has already been practiced for more than one century $(1,3,4)$. In this process food materials are compressesed within a cylinder by a piston and forced through a shaping orifice. The extrusion process can be made continuous by replacing the piston by a helical screw. Material is fed into an inlet hopper and moved forward by rotation of the screw. As it reaches the die, the pressure increases to the level required to force the material through the die orifice. The rotating screw transports material from inlet to discharge as a result of the slipping of material on the screw surface. The friction between material and screw surface results in shearing and heating of the material. The first major commercial application of the screw extrusion technology in the food processing industry was the pasta production in the mid 1930s. This is a low temperature, low shear process that remains a standard production technology in the beginning of the new millennium. Conventional pasta products are processed with a forming single-screw extruder only to the level necessary to bind the moistened mass and produce a desired shape.

Extrusion cooking is a continuous process by which food biopolymers and ingredients are mixed, plasticized, cooked and formed by combination of moisture, temperature, pressure, and mechanical shear (2). The first extrusion cooked, expanded food products - corn snacks - were commercially produced just after the Second World War using high shear extruders to process starch gelatinization or cooking of extrudate completely in one step. Because of the temperature and moisture conditions in this extrusion process a post die expansion of extrudate takes place resulting in a light and crispy product. During this past half-century food extrusion has developed from a simple pressing and forming technology into sophisticated cooking processes, which have replaced many conventional technologies in food processing.

A variety of machines with widely different processing and mechanical characteristics are used today in the food extrusion technology, including various types of single- and twin-screw extruders. 
Each extruder type has a very distinct operating principle, function, and application in processing. The single-screw extruders have been successfully employed in food production over the past 60 years. However, twin-screw extruders, which were introduced in the food industry some 30 years ago, found more and more applications in food processing because they offer greater flexibility in controlling both, product and process parameters $(1,2,5)$. Various types of twin-screw extruders can be categorized according to the direction of screw rotation and to the position of screws in relation to one another. In the co-rotating twin-screw extruders the screws rotate in the same direction, whereas in the counter-rotating extruders the screws move in opposite directions (Fig.1). Regarding position, twin-screw extruders can have intermeshing screws in which the flights of one screw penetrate the channels of the other screw, or nonintermeshing screws in which the screws do not engage each other threads. The twin-screw extruders of most interest for applications in food processing are the following fully intermeshing types: a) co-rotating twin-screw extruder, which today is the most used twin-screw extruder in food processing, b) counter-rotating twin-screw extruder, and c) conical, counter-rotating twin-screw extruder.

The main difference between the single and the different twin-screw extruder types is the conveying mechanism or the method of pressure development. The single-screw extruder is a drag flow device (6). The drag or friction against the barrel wall keeps the material from turning with the screw and, therefore makes it advance along the barrel. The non-intermeshing twin-screw extruders work like single-screw extruders, but have a higher capacity. The intermeshing, counter-rotating twin-screw
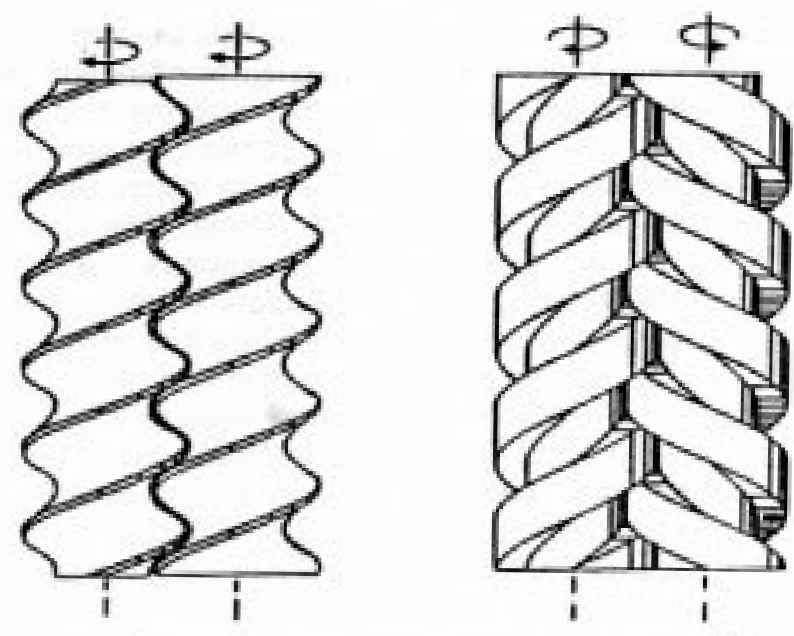

Fig. 1

Twin-screw extruder: a) co-rotating screws b) counter-rotating screws extruder functions like positive displacement pumps. Extremely high die pressures can be achieved because the dough mass is moved forward in separate, C-shaped chambers (6). Also, this extruder type has a narrow residence time distribution (7). The conveying and compressing capabilities of an intermeshing, conical, counter-rotating twin-screw extruder can exceed those of the other intermeshing types. The flow behavior of the intermeshing, co-rotating twin-screw extruder is therefore a combination of the other two types: It acts as a viscous drag pump with some positive displacement characteristics (8).

The most practical way to classify extruders is the intensity with which the extrudate is sheared within the extruder (5). Mechanical energy input increases with increasing shear intensity and product temperature increases in relation to the energy dissipation and heat transfer. According shear intensity, single-screw extruders can be classified as: a) low-shear forming extruder, b) low-shear cooking extruder, and c) high-shear cooking extruder. Single screw extruders have a relatively uniform shearing but a poor material mixing. Typical operating conditions for various types of the cooking extruders are represented in Table I.

The mechanisms and intensity of shearing in the twin-screw extruders depend on the extruder type. Increased mixing, heat transfer, and the mechanical energy dissipation occur in sections of the twin-screw extruder, which are completely filled. To increase the mechanical energy dissipation and enhance mixing, restrictive elements such as cut flight screws, kneading discs, reverse screw elements, barrel valves, and other shearing elements are used. The screw configuration can have a drastic effect on the temperature and pressure profile, energy consumption and residence time distribution. The twin-screw extruder is generally operated in starve fed mode, which means the screw speed exceeds the feed rate. Thus, the screw speed in twin-screw extruders can be changed to vary the mechanical shear rate so that different product textures can be produced from the same formulation with the same screw pair. Screw speed in a twin-screw extruder can also be used to compensate some variations in the properties of the raw materials.

Traditionally, extruders have been considered to have three basic processing zones: feeding zone, metering or transition zone and the final cooking zone (2). The screws can have various sections, which perform different functions in the respective processing zones (Fig. 2). The initial feeding sections of the screw profile are designed to convey ingredients into the machine. In the following metering zone raw materials are compressed to form plasticized dough or melt. The final cooking zone has screw sections which allow high shearing and high 
Table I

\section{Typical operating conditions for various types of cooking extruders (adapted from ref. 10 and 14)}

\begin{tabular}{|c|c|c|c|}
\hline \multirow[t]{2}{*}{ Variable } & \multicolumn{2}{|c|}{ Single-screw cooking extruder } & \multirow{2}{*}{$\begin{array}{l}\text { Twin-screw } \\
\text { cooking extruder }\end{array}$} \\
\hline & Low-shear & high-shear & \\
\hline Feed moisture (\%) & $25-28$ & $11-20$ & $11-35$ \\
\hline Product temperature $\left({ }^{\circ} \mathrm{C}\right)$ & $70-150$ & $120-200$ & $80-200$ \\
\hline Screw speed (rpm) & $40-200$ & $300-500$ & $70-500$ \\
\hline Shear rate $\left(\mathrm{s}^{-1}\right)$ & $10-100$ & $120-180$ & $100-200$ \\
\hline Mechanical energy $\left(\mathrm{kJkg}^{-1}\right)$ & 140 & $360-400$ & $140-400$ \\
\hline Barrel Heat $\left(\mathrm{kJkg}^{-1}\right)$ & $0-110$ & $(-110)-0$ & $(-110)-110$ \\
\hline Steam injection $\left(\mathrm{kJkg}^{-1}\right)$ & 110 & 0 & 0 \\
\hline Net energy input $\left(\mathrm{kJkg}^{-1}\right)$ & $100-360$ & $290-400$ & $140-510$ \\
\hline \multirow[t]{2}{*}{ Product type } & RTE cereal pellets, half & Puffed snacks, & Puffed snacks, \\
\hline & $\begin{array}{l}\text { product snacks, soup bases, } \\
\text { soft-moisture products. }\end{array}$ & $\begin{array}{l}\text { RTE cereals, modified } \\
\text { starch }\end{array}$ & $\begin{array}{l}\text { RTE cereals, modified } \\
\text { starch, fabricated chips }\end{array}$ \\
\hline
\end{tabular}

compression of the processed material. Kneading sections equipped with cut flight screws or other kneading elements can be used in the metering and cooking zones. However, by changing the screw profile in twin-screw extruders, new combined functions can be obtained (5). Pressure profile down the length of the barrel on twin-screw extruders can be varied using restrictive elements to allow steam injection or venting with partial cooling of ingredients and/or incorporation of additional ingredients (Fig. 2). The extruder barrel is normally equipped with jacketed sections, which can be heated and/or cooled to permit modification of temperature along the length of the barrel. The extruder die is the last restrictive element in an extruder, which causes the last

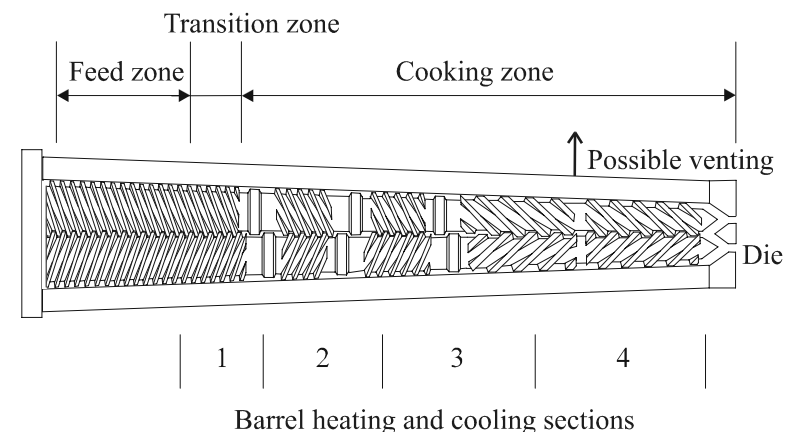

Fig. 2

A screw configuration example in a conical, counter-rotating twin-screw extruder pressure built up to form the material before discharge. The fixed die plate at the outlet can have some forming orifices to shape the extruded product. Cutter knifes, positioned at the end of the die, slice the extruded product into a specified length. Depending on extrusion cooking conditions and raw materials, the extruded products can be direct expanded extrudates or unexpanded pellets. If extrusion takes place under high temperature direct expanded products are obtained at the die plate as a result of the sudden moisture evaporation.

Extrusion cooking as a high temperature - short time process offers several advantages in the food processing. The most significant advantage is that the process is continuous (2). These advantages are evident, especially in simplification of process techniques for the manufacture of existing products, as well as in development of new foods (9). During extrusion cooking the material receives a short input of mechanical and thermal energy that is sufficient to bring about changes in structure and composition similar to those caused by conventional food processing operations, such as cooking, baking, roasting, gelatinize, caramelize, react and heat sterilization. Extrusion cooking can thus be applied in development of new processes for production of existing foods and/or in development of novel products with unique texture. Depending on their design, food extruders can also be used in many unit operations like mixing, kneading, drying, melt, crystallize, texturize and shape (9). The cooking extruders have found many applications in food and feed processing (10), which include: 
A) Ready to eat breakfast cereals (RTE): Expanded RTE cereals are manufactured from mixtures of cereal flours and starches combined with small amounts of malt, fat, sugars, emulsifiers, and salt (11). Extrusion is one of many techniques to manufacture RTE cereals. Extrusion cooking has become the preferred technology because it accepts both cereal and starch ingredients, creates highly expanded products, produces a wide variety of shapes and textures, cooks and forms in a single processing step, and works at relatively low moistures (12).

B) Snack foods: One advantage of extrusion cooking in snack food production is the ability to produce a wide range of finished products with minimum processing times using inexpensive raw materials (13). The snack food processes, which use extrusion cooking, include the production of direct expanded extrudate and extruded pellets or half products of the third generation snacks $(9,14)$.

The extruded half products require a secondary puffing step. Prior to consumption, the third generation snacks are puffed in a fryer, or expanded in hot air or a microwave oven (14). Snack food technology of direct expanded, and shaped snacks is similar to RTE cereals processes, but normally performed at lower moistures, so that a higher energy input from mechanical sources occurs (10). In general, direct expanded products are made using high-shear extruders. Other categories of the direct expanded foods are crisps or flat breads, which are produced using the twin-screw extruder technology $(9,14)$. Also, twin-screw extruders can be used for cracker production.

Coextrusion is a process that combines two different extruded streams to obtain two-component products characterized by a dual texture and/or color (1). The most common form of coextrusion in snack food industry has been the extrusion cooking of a cereal based outer tube with a filling pumped into the center of the tube using a coextrusion die (14).

Fats and oils play an important role in frying, coating and filling of the extruded snack foods. Coating with oil and seasonings is the final processing step in the production of snack foods (15). The seasonings allow the manufacturer to create a variety of flavors. The oil is the carrier of seasonings and gives the extrudate a better mouth feel. The oil and seasoning coating usually makes up to $35 \%$ of the finished product (14).

C) Other cereal based products: Extrusion cooking is widely used in the food industry for production of pregelatinized flours and starches, soup bases, extruded breadings, extruded weaning foods, etc. $(9,16)$. Recently, continuous production of roux using the twin-screw extrusion technology was published (17).

D) Pet foods and aquatic foods: Pet foods, aquatic foods and other animal foods or feeds are important cereal-based products, produced, pasteurized and shaped by extrusion cooking (18). They consist of a mixture of cereals, vegetable proteins, meat by-products, fat, flavors and vitamins. Pet foods represent the greatest volume of extruded products on the market (10), which include dry expanded and unexpanded semimoist products. Occasionally, fat and other flavors are enrobed on the surface of the dry pet foods to increase palatability and to provide a unique appearance (10). Also, coextruded pet foods as combinations of dry and semimoist pet foods are produced (18).

Expansion of the final extruded product is an extrusion technology tool to control product density in the manufacture of the floating or sinking aquatic foods.

E) Texturized vegetable protein: Cross-linking reactions of the vegetable protein during extrusion cooking leads to form fibrous meatlike structure that can be used as meat substitute in a variety of foods $(10,19)$. The texturization of defatted soy protein using the single-screw extrusion technology is done routinely (10). Twin-screw extruders are used to process dehulled whole soybeans containing approximately $20 \%$ fat (20).

F) Confectionery products: Twin-screw extruders are able to mix well the material, to control temperatures of the heat sensitive materials and to incorporate additional fat, milk, sugars, nuts, and other ingredients, which are used in the confectionery industry $(10,21)$. Extruded candy products include licorice, toffees, caramels, fudges, croutons, gums, jellies, etc. $(9,10,21,22)$. Twin-screw extrusion technology can be used to process in one step the coating grade chocolate (10), and the injection moulded or formed chocolate articles (23).

G) Chemical and biochemical reactions: Extrusion technology is used successfully to perform chemical modifications in the food industry, including caseinate production (10), starch modifications (9, $10)$, isomerization reactions in the hop processing (24), and as a reactor of flavor formation $(25,26)$. These reactions require high temperatures and pressures and the precise control of the residence time and the temperature-time profiles. Also, twinscrew extruders can be used as biochemical reactors for the enzymatic starch liquefaction (27-30). Counter-rotating twin-screw extruders are preferred as chemical or biochemical reactors because of their narrow residence time distribution (7).

H) Applications of extruders for oil extraction: Long shaft single-screw extruders with interrupted flights screw often-called expanders, are used in oil seed processing (31). Extrusion cooking gives the oil seed materials a porous structure, which improves mechanical oil expression and solvent oil extraction (32). Also, extrusion cooking inactivates lipase and other fat hydrolyzing enzymes. Recently, some studies 
were published about the optimization of the oil seeds extrusion process (33-35): Bargale et al. (33) studied the optimization of oil recovery from extruded soybean processed using three different kinds of extruders in the pretreatment step for subsequent mechanical oil expression. Omobuwajo et al. (34) developed a theoretical model for the screw expeller processing, which may be useful in the simulation, design and optimization of the screw expeller processes. Dufaure et al. (35) investigated the one step processing of extrusion pretreatment and direct mechanical expression of oleic sunflower seeds in an optimized twin-screw extruder. High pressing temperature and low moisture content improved oil extraction. The pressing of oleaginous material in a twin-screw extruder provides a new option to traditional processes.

\section{LIPIDS AS INGREDIENTS IN THE EXTRUSION COOKING PROCESSES}

The food components that play an important role in the extrusion cooking processes are: starch, proteins, lipids, low molecular sugars, and fibers. During extrusion cooking the raw materials are transformed and manipulated in the way to provide products with a unique structure and texture. The natural biopolymers, starch and occasionally some proteins play an important role on structure formation of the extrusion-cooked products. Under the conditions of extrusion cooking (high temperatures, pressures and shear forces) starch granules are disrupted and melted at low moisture contents or swelled and gelatinized at high moistures (36). In both cases starch conversion leads to the loss of crystalline structure to form an amorphous phase, which in extrusion cooking of the starch rich materials results in a fluid mass with starch biopolymers in the continuous phase. This helps to retain the gases released during the expansion process at the extruder die, enabling the formation of expanded foam structures. The amount of polymer, which is found in the continuous phase determines the extensibility of bubble cell walls in the foam and therefore the overall expansion of extrudate at the die (37).

The other particulate matter of the extrusion-cooked mass, proteins, fibrous materials, and the high temperature melting starches, form dispersed phases within the main structure of the starch biopolymers. If food extrudates are examined by microscopy, they show a continuous starch phase and a number of substances, which are dispersed in the continuous phase $(38,52,91)$. The size of dispersed particles is influenced by the shear intensity in the extruder. The dispersed materials modify melt viscosity (39), and behavior of the melt flowing through the die and the channels or gapes of the screw. The amount of the melted biopolymer which forms the continuous phase depends on the conditions of extrusion cooking: temperature, moisture, pressure, shear and residence time. Also, high temperatures and high shear intensities result in extrusion cooking in raptures of biopolymer bounds and other crosslinking reactions, which change flowing properties of the melt (36). The extrudate expansion at the die is a response of the rheological properties of the melted starch biopolymers, viscosity and elasticity $(40,41)$, which depend on the temperature and shear history of the materials during extrusion cooking (42). The relationship between extrusion conditions and the structure of the extruded product is possibly one of the most important problems in extrusion cooking.

Some materials including water, lipids and low molecular sugars, act as plastificizer in the extrusion cooking processes (37). They increase the mobility of the food polymer, and consequently decrease melt viscosity, and melting and glass temperatures of the biopolymer. Shearing and friction of biopolymers such as starch and proteins during extrusion cooking causes a large dissipation of mechanical energy due to viscous and frictional effects. The decreased viscosity by the plastificizer decreases the shearing and the mechanical energy input in the cooking extruder. These in turn negatively affect melting of the structure-forming biopolymer (43), and consequently extrudate expansion. Also, the decreased glass temperature due to plastificizer can play an important role on structure changes in the extrudate after expansion at the die (44). Thus, plastificizers can be used to control the mechanical energy input in extrusion cooking processes and the functional properties of the extrudate.

Emulsifiers are special forms of lipids, which tend to have higher melting points than triglycerides but behave as oils to provide lubrication in the extrusion cooking processes (37). Several types of emulsifiers as fatty acids, monoglycerides and their esters form complexes with the amylose fraction of the starch, which provide a protective layer at the surface of starch granules during extrusion cooking. These affect more significantly texture and stickiness of the extrudate. Today, emulsifiers are used as standard ingredients in many extrusion cooking processes.

The raw materials in the extrusion cooking processes cover various combinations of ingredients including: cereals, grains and starches, tubers, legumes, oil seeds, pseudocereals, as well as animal fat and proteins. The contents of the main components of some important raw materials for the extrusion cooking processes are represented in Table II. The most commonly used starch-based structure forming materials are maize, wheat, rice, and potato products (37). Other cereals and starch rich materials, less common used, are rye, barley, oats, sorghum, cassava, tapioca, buckwheat, pea, amaranth and 
Table II

Approximate composition of raw materials in extrusion cooking processes (\% weight fractions)

\begin{tabular}{|c|c|c|c|c|c|}
\hline & Moisture & Starch & Protein & Lipid & Crude fiber \\
\hline Maize, whole & $11-12$ & 73 & $7-10$ & 4 & 3 \\
\hline Maize flours & $11-15$ & $76-81$ & $6-10$ & $0.8-2$ & $0.4-0.5$ \\
\hline Wheat, whole & $11-13$ & 64 & $10-13$ & 2 & 3 \\
\hline Wheat flours & $12-14$ & $74-80$ & 8-15 & $1-2$ & $1-2$ \\
\hline Rice, whole & $10-12$ & 78 & 7 & $2-3$ & 2 \\
\hline Rice flours & $10-12$ & $77-81$ & $7-9$ & $0.3-0.5$ & $0.3-0.4$ \\
\hline Potato flours & $5-11$ & $80-85$ & $5-9$ & $0.1-2$ & $2-10$ \\
\hline Oat flours & $7-10$ & $50-62$ & $10-16$ & $5-8$ & $2-12$ \\
\hline Rye & $11-13$ & 61 & $8-10$ & $1-2$ & 3 \\
\hline Barley & $11-13$ & $68-73$ & $10-11$ & 2 & 3 \\
\hline Sorghum & $11-13$ & $68-72$ & $10-11$ & $2-5$ & 7 \\
\hline Buckwheat & $11-13$ & 71 & $8-10$ & $1-2$ & 4 \\
\hline Amaranth & $10-12$ & 57 & $14-15$ & $6-9$ & 3 \\
\hline Quinoa & $10-12$ & 61 & $12-14$ & $5-7$ & 4 \\
\hline Soy, beans and flours & $6-10$ & 6 & $45-53$ & $16-21$ & 3 \\
\hline Soy concentrates & $5-9$ & $10-12$ & $65-70$ & $0.2-0.3$ & $3-4$ \\
\hline Soy isolates & $5-7$ & 0 & $90-92$ & $0.2-0.3$ & 0 \\
\hline
\end{tabular}

quinoa. For directly expanded products, starch content up to $60 \%$ (dry basis) is required for good expansion. Physical attributes of the various materials, such as particle size (flour, grit, starch), density, and the mechanical properties and rheology highly influence their extrusion cooking behavior (45). Moreover, nutritional ingredients and functional ingredients (e.g. fiber, soy protein, whey powder, sugar, salt, emulsifier) are important in the mixture formulation of the extrusion cooking processes. Also, the ingredients can include nucleating agents to enhance the numbers of bubbles in the extrudates and produce finer structures, colors or color-forming substances, etc. (37).

If the main structure of the melted product is formed from proteins, oil seeds proteins like soy or sunflower, beans, and wheat gluten are commonly used as raw materials in the extrusion cooking processes.

\section{EFFECTS OF OILS AND OTHER LIPIDS ON EXTRUSION COOKING}

In general, adding about $0.5 \%$ vegetable oil to a cereal-based mixture significantly decreases the specific mechanical energy input in the low moisture extrusion cooking, if the other extrusion variables are kept constant (45). The loss of mechanical energy input will be reflected in decreasing mass temperature and increasing die pressure. Oils and fats provide a powerful lubrificant effect in the compressed polymer mix during extrusion cooking. Under extrusion cooking conditions all lipids become oils as the mass temperature rise to their melting points. They are mixed into the extrudates by the shearing action of screw elements and are dispersed into very small drops $(<1 \mu \mathrm{m})$, but if the oil or fat concentration exceeds a critical point they are smeared out on the biopolymers (37). Lipids have to be thoroughly mixed before or during extrusion otherwise oil separation takes place (46), which lubricates the screw and barrel surfaces, reducing the friction factor. The role of oils and lipids as lubrificants can be observed in the low moisture extrusion of starches with low lipid content such as potato starch. At low moisture these starches overheat at metal surfaces, which create problems concerning the flow behavior and cause eventually blockades due to intensive formation of starch degradation products. Addition of 0.5 to 
$1.0 \%$ vegetable oil provides stabilization and normalization of the extrusion processes. Also, small portions of added oil would improve expansion, texture and other extrudate properties. The choice of the added oils in extrusion cooking may be based on their functional effects, chemical stability and sensory qualities of the product. Unsaturated oils are subject of increasing oxidative degradation (47).

Effects of added oil or lipid ingredients on melt viscosity in extrusion cooking were published in some studies $(39,48,49)$. Wang et al. (39) investigated the effects of palm oil and other ingredients on the melt viscosity of wheat dough processed in a twin-screw extruder. They reported a complex relationship of the added oil on melt viscosity. Melt viscosity increased when the added oil concentration increased from 0 up to $1 \%$ and decreased sharply at higher concentrations. The lubrification of the flour particles by the oil tend to protect the starch granules. At low moisture content starch dispersal is achieved purely by the mechanical shearing of the starch granules (37). Therefore, these are less degraded and give a higher viscosity in the melt fluid at low added oil levels. Further increasing of the added oil concentration up to $2-3 \%$ markedly prevents the starch dispersal, which decreases sharply the melt viscosity.

The addition of lipids in small quantities ( $<3 \%$ ) in extrusion cooking has only a low effect on the extrudate expansion at the die, while amounts over $5 \%$ result in rapid decreases of extrudate expansion (36). The decreased mechanical energy input, due to the high lipid level, lead to an undercooked dough with a low amount of dispersed starch in the continuous phase that causes the reduction of the overall die expansion of extrudate. In extrusion cooking at higher oil levels, the direct expanded extrudate show a biscuit-like texture instead of a sponge structure. Thus, the surplus of fat modifies the eating qualities of the low moisture extruded product (37). Jager et al. (46) reported the possibility of up to $13 \%$ sunflower oil addition to maize grits and uniformly mixing in a twin-screw extruder if the oil injection happened after the material had passed a shearing zone of the screws, so starch conversion occurred prior to the oil addition. Also, foam-type structures could be formed in extrusion cooking at high oil contents at high moisture levels $(30-35 \%)$, where the starch conversion is not dependent on granule dispersal but on swelling and diffusion mechanisms (37).

Several studies investigated the direct oil addition in the extrusion cooking of starch-based materials: Mohamed (50) added corn oil up to $4 \%$ to maize grits and showed that expansion increased with increasing oil content. Faller and
Heymann (51) studied the vegetable oil addition up to $4 \%$ to potato meal or flakes and observed that oil content increased expansion and fracturability of the extrudate. Bhatnagar and Hanna (52) investigated the addition of palm, peanut and coconut oils in extrusion cooking of corn starch. Extrudate structure and texture were examined. The oil amounts of up to $4 \%$ resulted in extrudates with increased pore volumes, larger sized cells, lower bulk densities and lower shear strengths. Pan et al. (53) characterized extrusion cooking of rice flour with up to $5 \%$ soybean oil addition using the response surface methodology. They reported optimal product properties as expansion ratio and extrudate crispness at a level of about $3 \%$ oil content, whereas the water solubility index and stickiness of mouthfeel increased. Badrie and Mellowes (54) found that extrudate expansion and bulk density of extrudates made from cassava flour with up to $7 \%$ soybean oil were optimal at about $4 \%$ oil. Singh and Smith $(48,55)$ investigated extrusion cooking and extrudate properties of natural oat flour with an oil level of about $8 \%$, and whole wheat flour and wheat starch with up to $8 \%$ wheat germ oil addition. They reported that melt viscosity and extrusion behavior depended on the cereal type. Also, the whole oat flour had lower expansion as whole wheat flour with an wheat germ oil addition. Other investigations on extrusion cooking of wheat starch with up to $8 \%$ added wheat germ oil (56) showed that the expansion ratio of the extrudate markedly increased for oil levels up to $4 \%$.

The extrusion cooking behavior of full-fat oil seeds is described in some publications. Hsieh et al. (57) investigated processing of whole cottonseed with approximately $18 \%$ fat in a twin-screw extruder for feed production. Effects of extrusion cooking variables on product properties such as hardness, density and color were studied. Horvath and Czukor (58) examined protein solubility of full-fat soy meal processed in a single-screw extruder. Hayashi et al. (20) used a twin-screw extruder to process dehulled whole soybeans with $20 \%$ fat. Textural properties of the extruded products were studied as functions of extrusion variables.

The extrusion cooking behavior of cereals and other starch-based materials is highly dependent on fat content. In most cases, defatting improves the extrusion cooking behavior and increase overall expansion of the direct expanded products (45). The role of defatting can be seen on the extrusion cooking behavior of maize, which is the most widespread cereal in the manufacture of direct expanded snack products. In most cases degerminated maize is used in those processes because it expands better than whole maize meal (37). The reason of better expansion is that the oil content is much lower in 
degerminated maize meal with an oil content of less than $1 \%$ compared to the whole maize meal with an oil content of about $4 \%$ (Table II). Other starch based materials with high fat content as oats, amaranth and quinoa are important in the extrusion cooking processes, because they are excellent sources of protein and/or fiber (Table II). Extrusion cooking of these materials is difficult because of the smearing out of the oil on the material surface. Ascheri et al. (59) reported the manufacture of instant wholemeal from quinoa with $10 \%$ fat in a single screw-extruder. Konstance et al. (60) carried out the production of a precooked mix from corn and soy containing $12 \%$ fat in a twin-screw extruder.

However, production of direct expanded extrudate is more difficult. Attempts to process full-fat oats by extrusion cooking have been hindered by the high natural oil content (37). Recently, it was found how direct expanded breakfast cereals with relatively high levels of whole oat flour can be produced. This requires longer barrel extruders typically with steam preconditioning (14). Ilo et al. (61) investigated the extrusion cooking behavior of whole amaranth seeds containing about $7 \%$ fat with rice flour additions in a conical, counter-rotating twin-screw extruder. In this trials free fat smeared out of the material at the beginning of material compacting in the screw, where amaranth seeds rupture. The free fat was then absorbed by melted starch in the following screw sections but at high amaranth levels free fat was always present in all sections of the screw. Thus, a relatively long residence time was required in the cooking zone for fat absorption (61). Therefore, additional starch must be used in extrusion cooking of those high fat materials to improve extrusion cooking behavior and product expansion. Usually, those fatrich materials are used as ingredients in the extrusion cooking processes at relatively low levels.

Some publications $(61,62)$ reported the investigations of extrusion cooking of starch-based mixtures of high fat level using the response surface methodology to find the optimal processing conditions and properties of direct expanded extrudate. Park et al. (62) investigated the extrusion cooking of defatted soy flour, corn starch and raw beef blends containing up to $5 \%$ fat in a single-screw extruder. They found that the optimal feed fat content of the blends for most product properties (expansion ratio, bulk density, shear force, water absorption and color) were at fat levels of $2.5-3.0 \%$. Ilo et al. (61) reported the optimal amaranth content as the fat rich component in rice flour and amaranth mixtures in the low moisture twin-screw extrusion cooking were at amaranth levels of $20-40 \%$ for the most product properties: extrudate expansion, density and breaking strength. Effects of amaranth content on torque and specific mechanical energy input in extruder, and density and breaking strength of extrudate are represented in Fig. 3.
Several other publications (63-65) investigated the role of glycerol as plastificizer on the extrusion processing of biodegradable thermoplastic starches, pure or in mixtures with fatty acids or vegetable oils as plastificizer and lubrificants for the production of packaging materials.

\section{REACTIONS DURING EXTRUSION COOKING RELATED TO LIPIDS}

During extrusion cooking, the raw materials undergo many chemical and structural transformations that lead to a variety of unique products. The chemical changes that occur include conversion (gelatinization and melting) of starch, denaturation and crosslinking of proteins, complex formation between amylose and lipids, Maillard reactions in the presence of sugars, and degradation reactions of polymers and other molecules. Extruders can be used as high-temperature short-time reactors to destroy antinutritional factors $(58,66-68)$ and undesirable enzymes or microbial species (67-74).

Lipid complexation with amylose is a very important reaction in extrusion cooking that affects structure formation and texture of the extruded products (see next chapter). However, some other reactions related to lipids such as lipid oxidation, lipid binding due to interactions with starch and proteins, destruction and formation of antioxidants, cis-trans isomerization of unsaturated fatty acids, and degradation of fat-splitting enzymes play an important role on the shelf life of extrudate and nutritional losses.

Effects of extrusion cooking on lipid oxidation are described in some studies (47, 69, 75-77). Generally, extrusion cooking resulted in an increased peroxide value, which was a consequence of high extrusion temperatures. However, Alvarez et al. (75) reported a decrease of lipid oxidation in twin-screw extrusion cooking of a meat based product as extrusion temperature measured at the die increased from 71 to $115^{\circ} \mathrm{C}$. Also, Rao and Artz (47) examined the lipid oxidation of a corn based mixture with soybean oil addition in a twin-screw extruder with varied barrel temperature from 115 to $175^{\circ} \mathrm{C}$. The peroxide value was negatively affected by temperature because of rapid decomposition of peroxides at elevated temperatures. They investigated also the oxidative stability of the extruded products during storage at $37^{\circ} \mathrm{C}$ where extrusion cooking at higher temperatures resulted in higher peroxide formation (47). The same results were observed for oxidative stability of other extrusion cooked products $(69,76)$. A possible explanation of this is an increase of content of transition metals in the extrudate induced by higher temperatures during extrusion cooking, which catalyzes lipid oxidation (47). Porosity and thickness of bubble cell walls, which increased contact area for oxygen 
a)

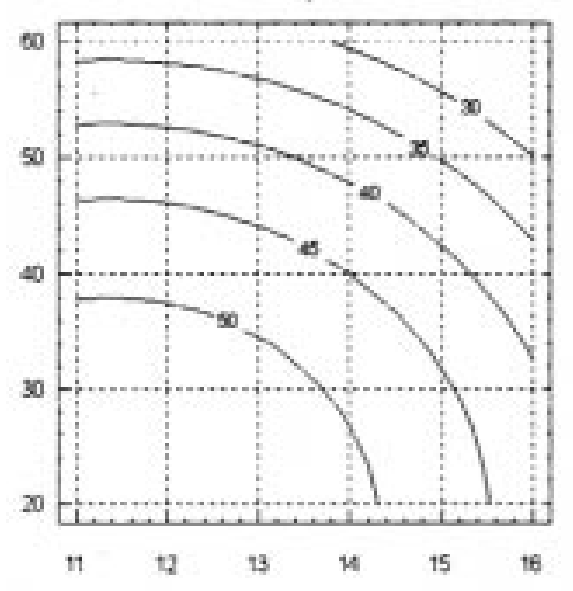

"Moisture

c)

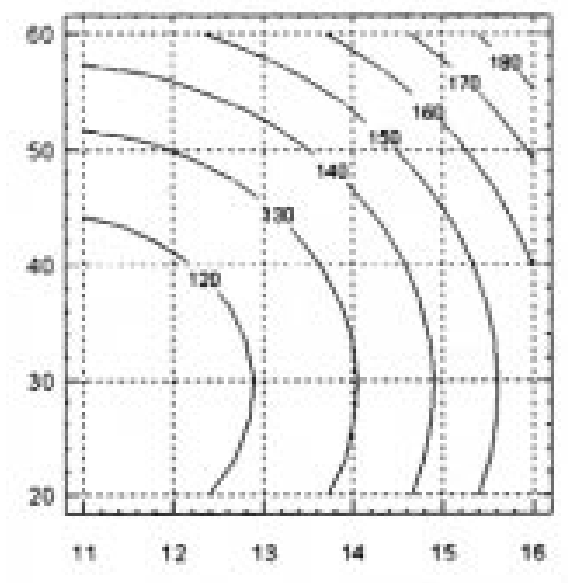

Moisture b)

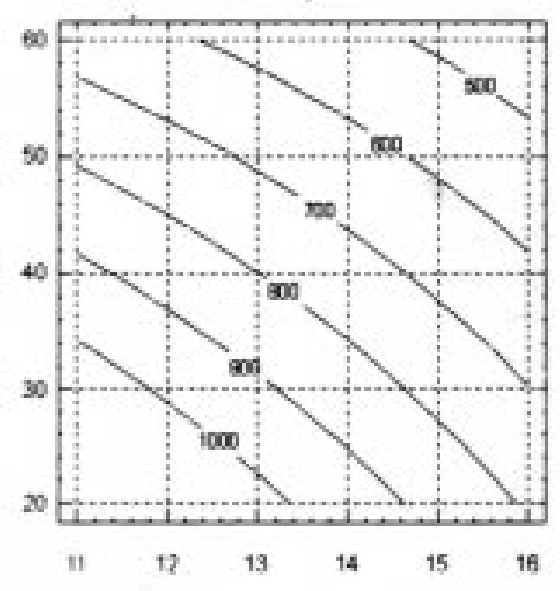

Moisture

d)

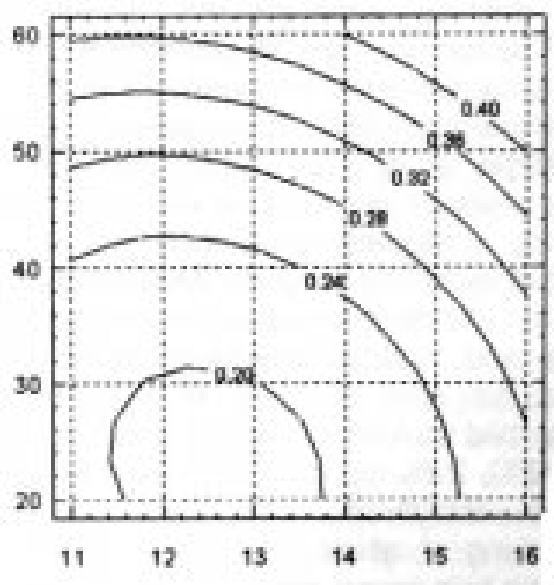

Moisture

Fig. 3

Effects of amaranth content as fat rich component and feed moisture (wet basis) in twin-screw extrusion cooking of rice flour amaranth blends: a) screw torque (\%), b) specific mechanical energy input in extruder $(\mathrm{kJ} / \mathrm{kg})$, c) product bulk density $\left.\left(\mathrm{kg} / \mathrm{m}^{3}\right), \mathrm{d}\right)$ breaking strength of extrudate $\left(\mathrm{N} / \mathrm{mm}^{2}\right)$

penetration in the extrudate, may be other factors that affecting the oxidative stability of the extrusion cooked products (76). Also, changes in the antioxidative substances occur during extrusion cooking. Increased extrusion temperature favor degradation of present natural antioxidants $(69,78)$, while other antioxidants are formed during extrusion cooking due to Maillard reactions in the presence of sugars, so that an optimal extrusion temperature could be expected for antioxidant activity of extrusion cooked products.
Lipid binding during extrusion cooking of starch-based materials was investigated in some studies $(76,79-81)$. Free lipids are defined as those that can be extracted with petroleum ether or hexane at room temperature, whereas the bound lipids are extractable with water-saturated butanol or chloroform-methanol mixtures (82). Ho and Izzo (79) investigated lipid binding due to interactions with starch and protein macromolecules in extrusion cooking of cornmeal. The most of the free lipids in the 
extruded material were bound. Lipid binding was significantly affected by feed moisture and extrusion temperature whereas screw speed was insignificant. However, Guzman et al. (80) showed that about twothirds of the free lipids were bound when cornmeal was subjected to the shear conditions in extruder. The amount of lipid bound was slightly dependent on extrusion temperature. Zadernowski et al. (76) studied the changes by extrusion cooking in oat lipids and found that extrusion cooking increased peroxide value in both free fat, and bound lipids. However, the bound lipids of extrudates contained a higher percentage of non-polar lipids, the peroxide value was lower than that of free fat. Thus, the binding of lipids during extrusion cooking may be one additional factor in the increased shelf life of extruded products.

Also, Zadernowsli et al. (76) reported that extrusion cooking affected the cis-trans position isomerism of double bonds in the fatty acids during extrusion cooking of oat.

Several studies concern the effects of extrusion cooking on hydrolytic rancidity (67-72). Kim and Park (67) used an extruder as high-temperature short-time reactor to destroy lipoxygenase activity and antinutritional factors in soy milk production. Results showed that extruder-barrel temperatures of $70-90^{\circ} \mathrm{C}$ effectively destroyed the lipoxygenase activity. However, Martin et al. (69) wrote that extrusion temperatures greater than $120^{\circ} \mathrm{C}$ in extrusion cooking would provide adequate protection against the development of hydrolytic rancidity. Meister et al. (70) investigated the effects of extrusion cooking on lipase, lipoxygenase and oxidase activity in some cereal brans (wheat, rye, corn and oat). All enzymes were inactivated at mild extrusion conditions (temperatures less than $120^{\circ} \mathrm{C}, 20 \%$ moisture and low mechanical stress). Also, Berghofer (71) when performing extrusion cooking of whole soybeans in a conical, counter-rotating twin-screw extruder demostrated that lipoxygenase activity was completely destroyed at a extrusion cooking temperature of $120^{\circ} \mathrm{C}$ and a low shearing screw configuration. Hayakawa et al. (68) used a twin-screw extruder as high-temperature shorttime reactor to destroy undesirable factors in dehulled soybeans. Lipoxygenase was completely inactivated in all of their experiments. Zhu et al. (72) examined effects of extrusion temperature and feed moisture on lipoxygenase activity during extrusion cooking of soybeans in a laboratory single-screw extruder. Destruction of lipoxygenase activity increased with increasing extrusion temperature and feed moisture.

\section{EFECTS OF AMYLOSE-LIPID COMPLEXATION ON EXTRUDATE QUALITY}

Several types of lipids including monoglycerides, fatty acids and their esters complex with the amylose fraction of the starch (82), significantly affect the extrusion cooking process and structure and functional properties of extrudate. These lipids can be used as emulsifiers in many extrusion cooking processes.

Adding of complex forming lipids or emulsifiers to the raw materials markedly influence the extrusion cooking process due to changes in melt viscosity and flow behaviour of the mass. Willett et al. (49) reported that an addition of monostearate to starch had no markedly effect up to $2 \%$ level, but slightly increased the melt viscosity up to $5 \%$ level. This behavior may be due to the unmelted helical amylose-lipid crystals, which are usually stable at extrusion cooking conditions $(38,83)$. Changes in melt viscosity markedly influence the extrusion cooking behavior and consequently the extrudate properties. Higher temperatures during extrusion cooking cause the melting of amylose-lipid complex which is reformed when cooling down during post-extrusion cutting and handling operations (37). Also, lubrification effects as a consequence of lipid addition may be important due to changes in flow behavior of the material. CondePetit and Escher (84) pointed out that the lubrification effect of mono- and tri-glycerides does not depend on their complexation ability.

The complex formation capacity in an extrusioncooked material is based on the amylose content, so that further addition of the complex forming emulsifier would negatively affects the extrusion cooking process due to lubrification effects. Bhatnagar and Hanna (85) investigated the complexing ability of some lipids, including fatty acids, monoglyceride, and tristearin during extrusion cooking of corn starches with various amylose contents. The amylose-lipid complex formation was measured by iodine-binding method. Maximum lipid complexing was observed in the extruded product of $70 \%$ amylose starch with myristic acid addition. Also, they determined the optimal extrusion cooking conditions for maximal complexing of stearic acid in a single-screw extruder using response design methodology (83). Maximum complexation was observed at barrel temperatures of $110-140^{\circ} \mathrm{C}$ and feed moisture of $19 \%$. In an other study (86) they characterized the amylose-stearic acid complex formation in a twin-screw cooking extruder by X-ray diffraction and reported that the complex formation started in the metering section of the extruder and continued up to the die, parallel to starch gelatinization. Singh et al. (56) investigated the effects on the extrudate properties of complexing lipids addition to wheat starch up to a level of $4 \%$. The added monoglyceride or fatty acids increased the V-type crystalinity in the extrudate due to starchlipid complex formation.

Effects of the complex forming lipids on extrusion cooking behavior were investigated in some other publications $(87,88)$. Hu et al. (87) 
studied the effect of the addition of up to $1.5 \%$ monoacylglycerol on the twin-screw extrusion cooking behavior and properties of the corn based extrudate. The added monoacylglycerol showed a lubrification effect at very low level. Increased emulsifier concentration decreased torque and the specific mechanical energy input, but increase pressure in extruder. The same effects were reported by Singh et al. (88) when studying the extrusion cooking behavior and extrudate properties in processing of maize grits with up to $1 \%$ monoglyceride in two different sizes of twin-screw extruders.

Also, Singh et al. (88) reported that the increased monoglyceride content in the raw material slightly increased the radial expansion ratio of the extrudate in both extruder scales used. However, other studies $(56,83,85,89-92)$ showed that the radial expansion index of extrudate decreased with increasing emulsifier concentration, whereas the longitudinal expansion increases. In an other publication Singh et al. (56) reported that the added complexing lipids decreased the radial expansion of the extrudate, whereas the addition of wheat germ oil at the same level showed the opposite effect. Ruy et al. $(89,90)$ examined the effects of glycerol monostearate, sodium stearoyl-2-lacturate and sucrose ester in up to the $1.5 \%$ level on physical properties of wheat flour extrudates. The increased emulsifier concentration showed a decrease of the radial expansion ratio and an increase of longitudinal expansion. Dextrumaux et al. (91) concluded the same when investigating the effects of added fatty acids on extrusion cooking of corn grits. As shown by Colonna et al. (93) semicrystalline amylose-lipid complex formation generates a rigid matrix that is less elastic. Because radial expansion is normally favored by the elastic properties of the melt, the loss of elasticity due to formation of amylose-lipid complex may explain the decrease in radial expansion, and consequently the increase in longitudinal expansion.

The complex formation between amylose and lipids during extrusion cooking has an important influence on structure, texture and other functional properties of the extrudate $(52,89-96)$. Bhatnagar and Hanna (52) investigated the addition of some complexing lipids or emulsifier including fatty acids and monoglycerides in extrusion cooking behavior of corn starch and the extrudate properties such as porosity, bulk density and shear strength. The added lipid at a level of up to $4 \%$ resulted in extrudates with lower porosity, small cells, higher bulk densities and larger shear strengths. Also, they studied the addition of different vegetable oils (palm, peanut and coconut oil) at the same level and reported that oil addition showed opposite effects on the extrudate structure. The negative effect of emulsifiers on the extrudate bulk density was reported in other studies $(83,89$, 90). Dextrumaux et al. (91) investigating the effects of added fatty acids on structure and textural properties of corn grits extrudate processed in a twin-screw extruder reported that the average cell size significantly decreased with increasing fatty acid content. Ryu et al. (90) noted the same for wheat flour extrudates with glyceryl monostearate addition. However, Ryu and Walker (94) demostrated that emulsifier addition provided wheat flour extrudate with more uniform and larger cell sizes.

Several investigations were undertaken about the effects of complexing lipids or emulsifiers of textural properties of extrudate. Some of them showed that emulsifier addition increased the breaking or shearing strength of the extrudate $(52$, 90). However, some other studies reported the opposite effect $(89,91)$. Dextrumaux et al. (91) studied the effects of free fatty acids on fracturability of the maize grits extrudate by puncture test, and found that the average puncturing force, average force of structural rapture and frequency of structural raptures were maximal at level of free fatty acids of about $0.4 \%$.

Pan et al. (53) published that addition of about $3 \%$ monoglyceride decreased the water solubility index and stickiness of the rice flour extrudate. Several other studies observed the same negative effect of emulsifier on the water solubility index $(56,91,92)$. However, Singh et al. (88) reported that addition of monoglycerides increased the water solubility index of maize grits. Ruy and Walker (95) and Ruy et al. (96) examined the effects of complexing lipids or emulsifier on the pasting properties of wheat flour extrudate and demonstrated that emulsifier addition increased peak temperature and decreased viscosity values. The study of Galloway et al. (92) reported that the amylose-lipid complex showed a low susceptibility by enzymes.

\section{LITERATURE}

1. Dziezak, J.D. (1989). Single- and twin-screw extruders in food processing. Food Technology, 43, 164-174.

2. Hauck, B.W. and Huber, G.R. (1989). Single screw vs twin screw extrusion. Cereal Food World, 34, 930-939.

3. Wiedmann, W. (1992). Improving product quality through twin-screw extrusion and closed-loop quality control. In: Food Extrusion Science and Technology. Kokini, J.L., Ho, C. and Karwe, M.V. (Eds), Marcel Dekker inc., New York, pp. 539-570.

4. Lusas, E. and Riaz, M. (1994). An introduction to extruders and extrusion principles. Extrusion Communique, 12/94, 9-34.

5. Harper, J.M. (1992). A comparative analysis of single and twin-screw extruders. In: Food Extrusion Science and Technology. Kokini, J.L., Ho, C. and Karwe, M.V. (Eds), Marcel Dekker inc., New York, pp.139-148. 
6. Frame N.D. (1994). Operational characteristics of the co-rotating twin-screw extruder. In: The Technology of Extrusion Cooking. Frame, N.D. (Ed), Blackie Academic \& Professional, London, pp. 1-51.

7. Fichtali, J. and van de Voort, F.R. (1989). Fundamental and practical aspects of twin screw extrusion. Cereal Food World, 34, 920-929.

8. Miller, R.C. (1990). Unit Operations and Equipment. IV. Extrusion and Extruders. In: Breakfast Cereals and how they are made. Fast, R.B. and Caldwell, E.F. (Eds), American Association of Cereal Chemists inc., St. Paul, MN, pp. 135-193.

9. Meuser, F. and Wiedmann, W. (1989). Extrusion plant design. In: Extrusion cooking. Mercier, C., Linko, P. and Harper, J.M. (Eds), American Association of Cereal Chemists inc., St. Paul, MN, pp. 91-154.

10. Harper, J.M. (1989). Food extruders and their applications. In: Extrusion cooking. Mercier, C., Linko, P. and Harper, J.M. (Eds), American Association of Cereal Chemists inc., St. Paul, MN, pp. 1-15.

11. Miller, R.C. (1994). Breakfast cereal extrusion technology. In: The Technology of Extrusion Cooking. Frame, N.D. (Ed), Blackie Academic \& Professional, London, pp. 73-143.

12. Caldwell, E.F., Fast, R.B., Lauhoff, C. and Miller, R.C. (1990). Unit Operations and Equipment. IV. Blending and Cooking. In: Breakfast Cereals and how they are made. Fast, R.B. and Caldwell, E.F. (Eds), American Association of Cereal Chemists inc., St. Paul, MN, pp. 43-86.

13. Sunderland, R. (1996). Production of third-generation snacks. Cereal Food World, 41, 12-14.

14. Moore, G. (1994). Snack food extrusion. In: The Technology of Extrusion Cooking. Frame, N.D. (Ed), Blackie Academic \& Professional, London, pp. 110-143.

15. Burns, R.T. and Fast, R.B. (1990). Application of nutritional and flavoring/sweetening coatings. In: Breakfast Cereals and how they are made. Fast, R.B. and Caldwell, E.F. (Eds), American Association of Cereal Chemists inc., St. Paul, MN, pp. 195-220.

16. Almeida-Dominguez, H.D., Gomez, M.H., Serna-Saldivar, S.O., Waniska, R.D., Rooney, L.W. and Lusas, E.W. (1993). Extrusion cooking of millet-cowpea weaning foods. Cereal Chemistry, 70, 214-219.

17. McPherson, C. and Gierus, M. (1998). Continous production of roux using twin-screw extrusion technology. Cereal Food World, 43, 626-628.

18. Rokey, G.J. (1994). Petfood and fishfood extrusion. In: The Technology of Extrusion Cooking. Frame, N.D. (Ed), Blackie Academic \& Professional, London, pp.144-189.

19. Kitabatake, N. and Doi, E. (1992). Denaturation and texturization of food protein. In: Food Extrusion Science and Technology. Kokini, J.L., Ho, C. and Karwe, M.V. (Eds), Marcel Dekker inc., New York, pp. 361-371.

20. Hayashi, N., Abe, H., Hayakawa, I. and Fujio, Y. (1992). Texturization of dehulled whole soybean with a twin-screw extruder and texture evaluation. In: Food processing by ultra high pressure twin-screw extrusion. Hayakawa, I. (Ed), Technomic Publishing, Lancaster, PA, pp. 133-146.

21. Best, E.T. (1994). Confectionery extrusion. In: The Technology of Extrusion Cooking. Frame, N.D. (Ed), Blackie Academic \& Professional, London, pp. 190-236.

22. Berghofer, E., Eder, A. and Stotter, S. (1992). Production of sugar caramel and caramel colour. Extrusion Communique, 5/92, 18-19.
23. Beckett, S.T., Craig, M.A., Gurney, R.J., Ingreby, B.S. Mackley, M.R. and Parsons, T.C.L. (1994). The cold extrusion of chocolate. Trans IChemE, 72, Part C, 47-54.

24. Westwood, K.T. (1994). Extrusion of brewers' hops. In: The Technology of Extrusion Cooking. Frame, N.D. (Ed), Blackie Academic \& Professional, London, pp. 237-250.

25. Maga, J.A. (1989). Flavor formation and retention during extrusion. In: Extrusion cooking. Mercier, C., Linko, P. and Harper, J.M. (Eds), American Association of Cereal Chemists inc., St. Paul, MN, pp. 387398.

26. Camire, M.E. and Belbez, E.O. (1996). Flavor formation during extrusion cooking. Cereal Food World, 41, 734-736.

27. Lee, Y.C. and Kim, K.T. (1990). Gelatinization and liquefaction of starch with a heat stable a-amylase. Journal of Food Science, 55, 1365-1372.

28. Rousel, L., Vieille, A., Billet, I. and Cheftel, J.C. (1991). Sequential heat gelatinization and enzymatic hydrolysis of corn starch in an extrusion reactor. Optimization for a maximum dextrose equivalent. Lebensmittel-Wissenschaft und Technologie, 24, 449458.

29. Linko, P. (1992). Twin-screw extrusion cooker as a bioreactor for starch processing. In: Food Extrusion Science and Technology. Kokini J.L., Ho, C. and Karwe, M.V. (Eds), Marcel Dekker inc., New York, pp. 335-344.

30. Grafelman, D.D. and Meagher, M.M. (1995). Liquefaction of starch by a single-screw extruder and post-extrusion static-mixer reactor. Journal of Food Engineering, 24, 529-542.

31. Bockisch, M. (1993). Fat and oils handbook. AOCS Press, Champaign, IL, pp. 377-444.

32. Gunstone, F.D. and Padley, F.B. (1997). Lipid technologies and applications. Marcel Dekker inc., New York, pp. 117-134

33. Bargale, P.C., Ford, R.J., Sosulski, F.W., Wulfsohn, D. and Irudayaraj, J. (1999). Mechanical oil expression from extruded soybean samples. Journal of the American Oil Chemists Society. 76, 223-229.

34. Omobuwajo, T.O., Ige, M.T. and Ajayi, A.O. (1999). Theoretical prediction of extrusion pressure and oil flowrate during screw expeller processing of palm kernel seeds. Journal of Food Engineering, 38, 469485.

35. Dufaure, C., Leyris, J., Rigal, L. and Mouloungui, Z. (1999). A twin-screw extruder for oil extraction: I. Direct expression of oleic sunflower seeds. Journal of the American Oil Chemists Society. 76, 1073-1079.

36. Harper, J.M. (1992). Extrusion processing of starch. In: Alexander, R.J. and Zobel, H.F. (Eds), Developments in carbohydrate chemistry. American Association of Cereal Chemists inc., St. Paul, MN, pp. 37-64.

37. Guy, R.C.E. (1994). Raw materials for extrusion cooking processes. In: The Technology of Extrusion Cooking. Frame, N.D. (Ed), Blackie Academic \& Professional, London, pp. 52-72.

38. Ollett, A.L., Parker, R., Smith, A.C., Miles, M.J. and Morris, V.J. (1990). Microstructural changes during the twin-screw extrusion cooking of maize grits. Carbohydrate Polymers, 13, 69-84.

39. Wang, S., Casulli, J. and Bouvier, J.M. (1993). Effect of dough ingredients on apparent viscosity and 
properties of extrudates in twin-screw extrusion cooking. International Journal of Food Science and Technology, 28, 465-479.

40. Kokini, J.L., Chang, C.N. and Lai, L.S. (1992). The role of rheological properties on extrudate expansion. In: Kokini J.L., Ho, C. and Karwe, M.V. (Eds), Food Extrusion Science and Technology. Marcel Dekker inc., New York, pp. 631-652.

41. Della Valle, G., Vergnes, B., Colonna, P. and Patria, A. (1997). Relations between rheological properties of molten starches and their expansion behaviour in extrusion. Journal of Food Engineering, 31, 277-296.

42. Smith, A.C. (1992). Studies on the physical structure of starch-based materials in the extrusion cooking process. In: Food Extrusion Science and Technology. Kokini J.L., Ho, C. and Karwe, M.V. (Eds), Marcel Dekker inc., New York, pp. 573-618.

43. Fan, J., Mitchell, J.R. and Blanshard, J.M.V. (1996). The effect of sugars on the extrusion of maize grits: II. Starch conversion. International Journal of Food Science and Technology, 31, 67-76.

44. Fan, J., Mitchell, J.R. and Blanshard, J.M.V. (1996). The effect of sugars on the extrusion of maize grits: I. The role of the glass transition in determining product density and shape. International Journal of Food Science and Technology, 31, 55-65.

45. Janes, D.A. (1993). Methods for assesing raw materials and extrudates. Ingredients Extra, 12/93, 9-34.

46. Jager, T., van Zuilichem, D.J., Stolp, W. and van't Riet, K. (1991): Residence time distributions in extrusioncooking. Part VI: Viscous dissipation in a drossel element in the feed zone of a counter-rotating, twinscrew extruder. Journal of Food Engineering, 12, 6782.

47. Rao, S.K. and Artz, W.E. (1989). Effect of extrusion on lipid oxidation. Journal of Food Science, 54, 15801583.

48. Singh, N. and Smith, A.C. (1999). Rheological behaviour of different cereals using capillary rheometry. Journal of Food Engineering, 39, 203-209.

49. Willett, J.L., Jasberg, B.K. and Swanson, C.L. (1994). Melt rheology of thermoplastic starch. In: ACS Symposium series 575: Polymers from agricultural coproducts. Fishman, M.L., Fridman, R.B. and Huang, S.J. (Eds), American. Chemical Society, Washington, DC., pp. 50-68.

50. Mohamed, S. (1990). Factors affecting extrusion characteristics of expanded starch-based products. Journal of Food Processing and Preservation, 14, 437-452.

51. Faller, J.Y. and Heymann, H. (1996). Sensory and physical properties of extruded potato puffs. Journal of Sensory Studies, 11, 227-245.

52. Bhatnagar, S. and Hanna, M.A. (1997). Modification of microstructure of starch extruded with selected lipids. Starch, 49, 12-20.

53. Pan, B.S., Kong, M.S. and Chen, H.H. (1992). Twinscrew extrusion for expanded rice products: processing parameters and formulation of extrudate properties. In: Food Extrusion Science and Technology. Kokini J.L., Ho, C. and Karwe, M.V. (Eds), Marcel Dekker inc., New York, pp. 693-709.

54. Badrie, N. and Mellowes, W.A. (1992). Soybean flour/oil and wheat bran effects on characteristics of cassava (Manihot esculenta Crantz) flour extrudate. Journal of Food Science, 57, 108-111.
55. Singh, N. and Smith, A.C. (1997). A comparison of wheat starch, whole wheat meal and oat flour in the extrusion cooking process. Journal of Food Engineering, 34, 15-32.

56. Singh, N., Cairns, P. Morris, J.P. and Smith, A.C. (1998). Physical properties of extruded wheat starchadditive mixtures. Cereal Chemistry, 75, 325-330.

57. Hsieh, F., Huff, H.E., Peng, I.C., Whittier, J.C. Schmitz, E.G. and Paterson, J.A. (1990). Studies of whole cottonseed processing with a twin-screw extruder. Journal of Food Engineering, 12, 293-306.

58. Horvath, E. and Czukor, B. (1993). Effect of extrusion temperature and initial moisture content on the protein solubility and distribution in full fat soybean. Acta Alimentaria, 22, 151-167.

59. Ascheri, J.L.R., Ramirez-Asquieri, E. and Carvalho, C.W.P. (1998). Manufacture of instant wholemeal flour from quinoa (Chenopodium quinoa Willd) by thermoplastic extrusion. Alimentaria, 292, 93-98.

60. Konstance, R.P., Onwulata, C.I., Smith, P.W., Lu, D, Tunick, M.H., Strange, E.D. and Holsinger, V.H. (1998). Nutrient-based corn and soy products by twin-screw extrusion. Journal of Food Science, 63, 864-868.

61. Ilo S., Liu Y. and Berghofer E. (1999). Extrusion cooking of rice flour and amaranth blends. LebensmittelWissenschaft und Technologie, 32, 79-88.

62. Park, J., Rhee, K.S., Kim, B.K. and Rhee, K.C. (1993). Single-screw extrusion of defatted soy flour, corn starch and raw beef blends. Journal of Food Science, 58, 9-20.

63. Onteniente, J.P., Etienne, F., Bureau, G. and Prudhomme, J.C. (1996). Fully biodegradable lubrificated thermoplastic starches: water desorption on extruded samples. Starch, 48, 10-16.

64. Hulleman, S.H.D., Kalisvaart, M.G., Janssen, F.H.P., Feil, H. and Vligenthart, J.F.G. (1999). Origins of the B-type crystalinity in glycerol-plasticised, compression moulded potato starch. Carbohydrate Polymers, 39, 351-360.

65. Bae, S.O. and Lim, S.T. (1998). Physical properties of extruded strands of hydroyxypropylated normal and high-amylose corn starch. Cereal Chemistry, 75, 449454.

66. Alonso, R., Orue, E. and Marzo, F. (1998). Effects of extrusion and conventional processing methods on protein and antinutritional factor contents in pea seeds. Food Chemistry, 63, 505-512.

67. Kim, B. and Park, J. (1995). Use of extruder in soymilk production to improve flavor and yield. Foods and Biotechnology, 4, 55-59.

68. Hayakawa, I., Urushima, T. and Abe, H. (1992). Deactivation of physiologically active substances in whole soybean by a twin-screw extruder. In: Food processing by ultra high pressure twin-screw extrusion. Hayakawa, I. (Ed), Technomic Publishing, Lancaster, PA, pp. 11-20.

69. Martin, D., Godber, J.S., Setlhako, G., Verma, L. and Wells, J.H. (1993). Optimizing rice bran stabilization by extrusion cooking. Lousiana Agriculture, 36, 13-15.

70. Meister, U., Schramm, G. and Symmank, H. (1994). Determination of activities of lipase, lipoxygenase and peroxidase in native and extruded cereal brans. Zeitschrift für Lebensmittel Untersuchung und Forschung, 199, 275-280.

71. Berghofer, E. (1992). Extrusion von Sojabohnen. Die Mühle + Mishfuttertechnik. 129, 707-708. 
72. Zhu, S., Riaz, M.N. and Lusas, E.W. (1996). Effect of different extrusion temperatures and moisture content on lypoxygenase inactivation and protein solubility in soybeans. Journal of Agricultural Food Chemistry, 44, 3315-3318.

73. Choudhury, G.S. and Gogoi, B.K. (1996). Protease inactivation in fish muscle by high moisture twin-screw extrusion. Journal of Food Science, 61, 1219-1222.

74. Likimani, T.A., Sofos, J.N., Maga, J.A. and Harper, J.M. (1990). Methodology to determine destruction of bacterial spores during extrusion cooking. Journal of Food Science, 55, 1388-1392.

75. Alvarez, V.B., Smith, D.M., Morgan, R.G. and Booren, A.M. (1990). Restructuring of mechanically deboned chicken and nonmeat binders in a twin-screw extruder. Journal of Food Science, 55, 942-946.

76. Zadernowski, R., Nowak-Polanska, H., Wicklund, T. and Fornal, L. (1997). Changes in oat lipids affected by extrusion. Nahrung, 41, 224-227.

77. Gutkoski, L.C. and El-Dash, A.A. (1999). Extrusion cooking effects on oxidative stability of oat coarse milling product. Pesquisa Agropecuaria Brasileira, 34, 119-127.

78. Zadernowski, R., Nowak-Polanska, H. and Rashed, A.A. (1999). The influence of heat treatment on the activity of lipo- and hydrophilic components of oat grain. Journal of Food Processing \& Preservation, 23, 177-191.

79. Ho, C.T. and Izzo, M.T. (1992). Lipid-protein and lipidcarbohydrate interactions during extrusion. In: Food Extrusion Science and Technology. Kokini J.L., Ho, C. and Karwe, M.V. (Eds), Marcel Dekker inc., New York, pp. 415-425.

80. Guzman, L.B., Lee, T.C. and Chichester, C.O. (1992). Lipid binding during extrusion cooking. In: Food Extrusion Science and Technology. Kokini J.L., Ho, C. and Karwe, M.V. (Eds), Marcel Dekker inc., New York, pp. 427-436.

81. Wicklund, T. and Mangus, E.M. (1997). Effect of extrusion cooking on extractable lipids and fatty acid composition in sifted oat flour. Cereal Chemistry, 74, 326-329.

82. Seiler, K. (1993). Die Bedeutung fetthaltiger Komponenten bei der Extrusion stärkehaltiger Rohstoffe. Gordian, 93/12, 195-197.

83. Bhatnagar, S. and Hanna, M.A. (1994). Extrusion processing conditions for amylose-lipid complexing. Cereal Chemistry, 71, 587-593.
84. Conde-Petit, B. and Escher, F. (1995). Complexation induced changes of rheological properties of starch systems at different moisture levels. Journal of Rheology, 39, 1497-1518.

85. Bhatnagar, S. and Hanna, M.A. (1994). Amylose-lipid complex formation during single-screw extrusion of various corn starches. Cereal Chemistry, 71, 582-587.

86. Bhatnagar, S. and Hanna, M.A. (1994). Starch-stearic acid complex development within single and twin screw extruders. Journal of Food Science, 61, 778-782.

87. Hu, L., Hsieh, F. and Huff, H.E. (1993). Corn meal extrusion with emulsifier and soybean fiber. Lebensmittel-Wissenschaft und Technologie, 26, 544-551.

88. Singh, N., Smith, A.C. and Frame, N.D. (1998). Effect of process variables and monoglycerides on extrusion of maize grits using two sizes of extruder. Journal of Food Engineering, 35, 91-109.

89. Ruy, G.H., Neumann, P.E. and Walker, C.E. (1994). Effect of emulsifiers on physical properties of wheat flour extrudates with and without sucrose and shortening. Lebensmittel-Wissenschaft und Technologie, 27, 425-431.

90. Ruy, G.H., Neumann, P.E. and Walker, C.E. (1993). Effects of some baking ingredients on physical and structural properties of wheat flour extrudates. Cereal Chemistry, 70, 291-297.

91. Dextrumaux, A., Bouvier, J.M. and Burri, J. (1999). Effect of free fatty acids addition on corn grits extrusion cooking. Cereal Chemistry, 76, 699-704.

92. Galloway, G.I. Biliaderis, C.G. and Stanley, D.W. (1989). Properties of structure of amylose-glyceryl monostearate complexes formed in solution or on extrusion of wheat flour. Journal of Food Science, 54, 950-957.

93. Colonna, P., Tayeb, J. and Mercier, C. (1989). Extrusion cooking of starch and starchy products. In: Extrusion cooking. Mercier, C., Linko, P. and Harper, J.M. (Eds), American Association of Cereal Chemists inc., St. Paul, MN, pp. 247-319.

94. Ruy, G.H. and Walker, C.E. (1994). Cell structure of wheat flour extrudates produced with various emulsifiers. Lebensmittel-Wissenschaft und Technologie, 27, 432-441.

95. Ruy, G.H. and Walker, C.E. (1993). Emulsifier effects on pasting properties of wheat flour extrudates with/without sucrose and shortening. Starch, 45, 65-70.

96. Ruy, G.H., Neumann, P.E. and Walker, C.E. (1993). Pasting of wheat extrudates contacting conventional baking ingredients. Journal of Food Science, 58, 567$573,598$. 